\title{
Ensemble Hindcast Experiments for the Flood Period over China in 1998 by Use of the CCSR/NIES Atmospheric General Circulation Model
}

\author{
By Hui-Jun Wang \\ LASG, Institute of Atmospheric Physics, Chinese Academy of Sciences, Beijing, China \\ Taroh Matsuno and Yoshio Kurihara \\ Institute for Global Change Research (IGCR), Frontier Research System for Global Change (FRSGC), \\ Tokyo, Japan
}

(Manuscript received 13 August 1999, in revised form 9 March 2000)

\begin{abstract}
Sets of numerical hindcast experiments were carried out to study the excessive rain that happened over China in 1998 by using an atmospheric general circulation model. The monthly sea surface temperatures for 1998 were prescribed as the model boundary conditions. The initial atmospheric conditions for each of the 30 member simulations were obtained from the daily reanalysis data for 00 UTC from April 1 to April 30, 1998. The initial conditions for snow mass, soil temperature, and soil wetness were prescribed as those of the model climatology.

The ensemble averages of the 30 member hindcast experiments captured the positive rainfall anomaly occurred over China in the summer of 1998 , with 5 degrees of northward shift. The observed patterns of summer geopotential anomalies were qualitatively reproduced as well. It was revealed that initial atmospheric anomalies in April have apparent impacts on the simulated flow patterns over Eurasia and the North Pacific, and rainfall anomalies over China during the summer of 1998. However, the overall results suggest that tropical sea surface temperature anomaly played a key role in the heavy rainfall over China in 1998.
\end{abstract}

\section{Introduction}

It is argued that the relationship between a regional climate, the El Nino and the Southern Oscillation (ENSO) cycle can be a main physical basis for short-term climate prediction over part of the tropical and extratropical areas around the globe (Zeng et al. 1997). The global and regional precipitation patterns associated with ENSO cycle were detected by Ropelewski and Halpert (1987), in which the signal over East Asia was rather weak. This generally weak relation between the East Asian precipitation, and the global sea surface temperature (SST) anomaly was supported by some potential atmospheric predictability studies using climate models (Palmer 1994; Kumar and Hoerling 1995; Dix and Hunt 1995; Brankovic and Palmer 1997; Rowell 1998). The study of Rowell (1998) also found that

Corresponding author: Hui-Jun Wang, LASG, Institute of Atmospheric Physics, Chinese Academy of Sciences, Beijing 100029, China. E-mail: wanghj@lasgsgi4. iap.ac.cn

(C) 2000 , Meteorological Society of Japan most locations in mid-latitudes $\left(40^{\circ} \mathrm{N}-60^{\circ} \mathrm{N}\right)$ have their highest model predictability during winter and spring, rather than summer. However, as Rowell (1998) noted, this kind of climate predictability related with the SST anomalies can only be regarded as the mean SST-induced climate predictability.

The impacts of global SST anomalies on a regional climate over the extratropics like East Asia may differ from one year (or one ENSO event) to another, because of the variations in the strength and distribution of global SST anomalies. The impacts of global SST anomalies may also depend to some extent on the temporal scales we are interested in (Lau and Weng 1998). Wu and Wang (1998) revealed that mid-latitude SST anomalies have significant impacts on the Asian summer atmospheric circulation as well as the tropical SST anomalies. The year 1998 is a year when the mid-latitude SST anomalies over the Atlantic and the western Pacific in the Northern Hemisphere were very strong (Fig. 1).

Another factor, which may lead to some predictability of the East Asian summer climate, is the 


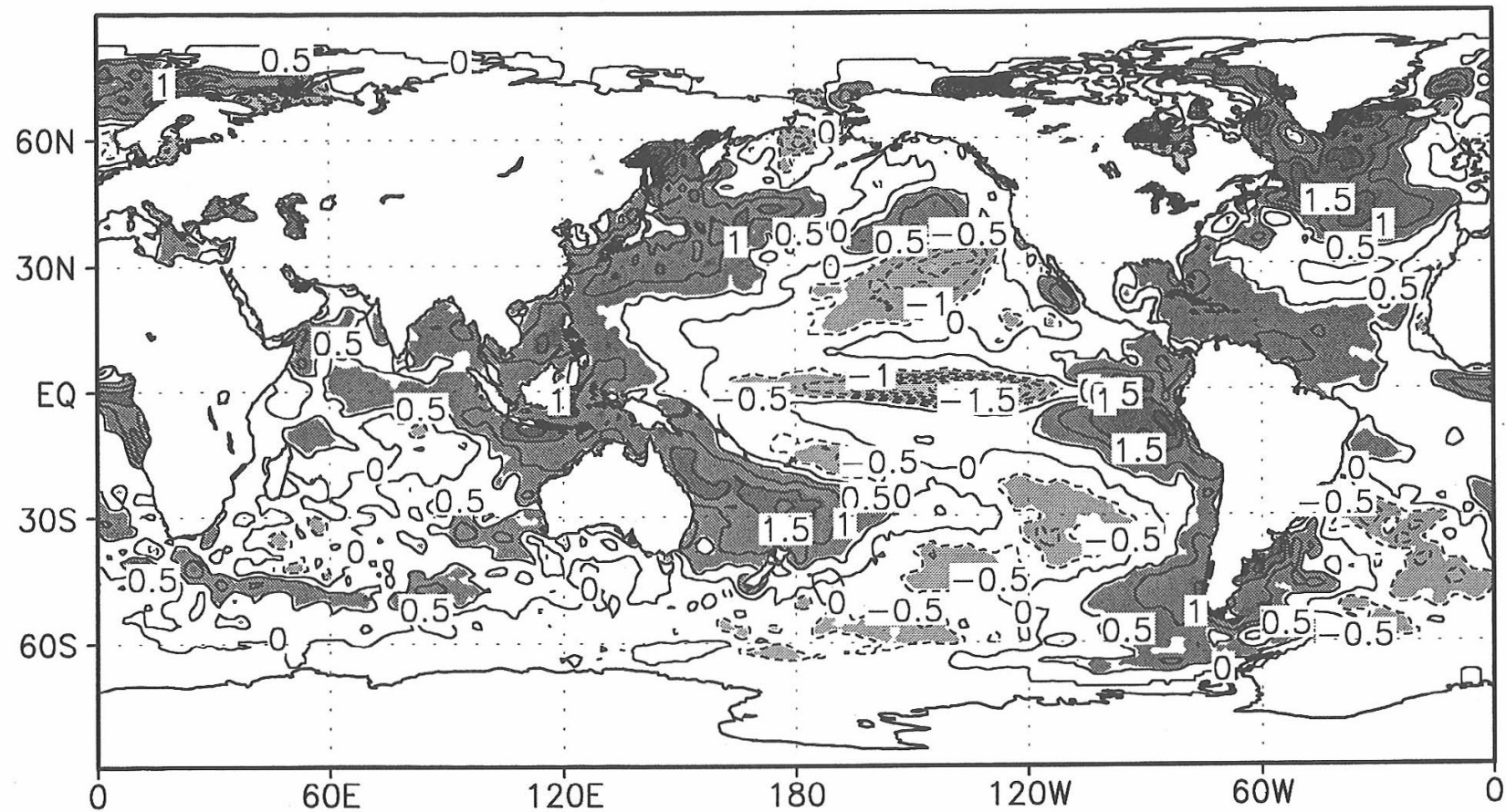

Fig. 1. The global distribution of observed June-July-August (JJA) SST anomalies (in ${ }^{\circ} \mathrm{C}$ ) (areas with magnitude of anomaly larger than $0.5^{\circ} \mathrm{C}$ are shaded).

relationship between the East Asian winter monsoon and the subsequent East Asian summer monsoon (Sun and Sun 1995; Ji et al. 1997). Through diagnostic and simulation studies, they found that the anomalies of atmospheric conditions (wind, geopotential height, and temperature) in the preceding winter and spring were significantly larger over Eurasia during the years with flood or drought summer over China than during the normal years. This empirical relationship may lead to a more realistic prediction on the East Asian summer climate in some years, in case the East Asian winter monsoon is significantly stronger or weaker than that in the normal years. It is interesting to note that positive anomalies of atmospheric geopotential height at $500 \mathrm{hPa}$ over Eurasia during winter and spring associated with the anomalous East Asian winter monsoon were very large in 1998.

Therefore the following questions arise for the climate prediction of 1998 :

(1) Can a state-of-the-art climate model simulate the East Asian summer climate anomaly (with the emphasis on the heavy rainfall over China) given the observed SST and initial atmospheric conditions of 1998 ?

(2) How much was the anomalous East Asian summer climate (including the heavy flood over China) influenced by the global SST anomalies?

(3) What role did the strong atmospheric anomalies in spring over Eurasia play in the summer climate anomaly over the East Asia?

To study the above issues, an atmospheric general circulation model (AGCM) was used to conduct a series of numerical experiments. The results are described in Sections 3 and 4, and summary in Section 5 .

\section{Model and experimental design}

The climate model used in this study is the AGCM developed jointly by the Center for Climate System Research (CCSR) at the University of Tokyo and the National Institute for Environmental Studies (NIES) of Japan (Numaguti et al. 1997). A T42L20 version is adopted which has the triangular 42 truncation and 20 sigma levels in the vertical. The lowest and the highest sigma levels are placed at sigma $=0.995$ and 0.008 , respectively. The orographic gravity wave drag is parameterized after Mcfarlane (1987). The radiative transfer scheme is based on the two-stream discrete ordinate method and k-distribution method. Radiative effects of water vapor, oxygen, ozone, nitrous oxide and methane are included. Penetrative and shallow cumulus convections are treated by the Relaxed Arakawa-Schubert (RAS) scheme of Moorthi and Suarez (1992), a modification of Arakawa-Schubert scheme (Arakawa and Schubert 1974). Large-scale (stratiform) cloud formation is determined by the prognostic cloud liquid water content (LWC) following Le Treut and Li (1991).

The land surface condition is classified according 
to the 32 vegetation types of Matthews (1983), but with only a locally dominant type specified for each grid box. Over the ice surface the albedo is a constant 0.7 . The albedo over the land surface is specified according to the vegetation type. For snowcovered land, the albedo increases over that of the background in proportion to a square root of the fractional snow cover. Over the ocean, the albedo depends on sun angle and the optical thickness of the atmosphere. Soil liquid water is predicted in a single layer according to the 'bucket' formation of Manabe et al. (1965). The moisture field capacity is spatially uniform $0.20 \mathrm{~m}$, with surface runoff occurring if the predicted soil moisture exceeds this value.

In the 20 years of the climatological run, monthly climatological SSTs and sea ice for the Atmospheric Model Intercomparison Project (AMIP) averaged over 1979-1995 were used as the boundary conditions. The SST data for 1998 in this study was that of Optimum Interpolation (OI) SST from the National Centers for Environmental Prediction (NCEP). Two groups of experiments (Group 1 and Group 2) were carried out besides the climatological run (CLIM), with 30 ensemble runs in each group. In Group 1 experiments, the monthly SSTs for 1998 were prescribed, while in Group 2, the climatological monthly AMIP SSTs were used. The daily reanalysis data from April 1 to April 30, 1998, of NCEP and National Center for Atmospheric Research (NCAR) was used as the initial atmospheric condition in the two groups of experiments. The initial conditions for soil temperature, soil moisture, and snow mass were prescribed as the model's climatology in April. In all the experiments, sea ice was prescribed at the same condition as the CLIM run. Detailed experimental design is described in Table 1.

The validation data sets are the monthly reanalysis data of NCEP/NCAR for 1998, the merged analyzed monthly precipitation by Xie and Arkin (1997), and the observed monthly outgoing longwave radiation data of National Oceanic and Atmospheric Administration (NOAA) of the USA.

\section{The ensemble average of the 30 member simulations}

First, the observed and simulated climatology of June-July-August (JJA) precipitation and winds at $850 \mathrm{hPa}$ over Asia and the western Pacific regions are presented in Fig. 2. The model reasonably simulates the observed rainfall distribution, especially the large amount of precipitation over the North Indian Ocean, the South China Sea, and the tropical western Pacific. However, we note that the model simulates slightly excessive rainfall over these regions and insufficient rainfall over the northern part of the East Asia. The simulated JJA wind pattern at $850 \mathrm{hPa}$ is quite realistic, although the magnitude
Table 1. The detailed description of the experimental designs.

\begin{tabular}{|l|l|l|l|}
\hline & CLIM & Group 1 & Group 2 \\
\hline SST & $\begin{array}{l}\text { Monthly } \\
\text { Climatological } \\
\text { AMIP SST }\end{array}$ & $\begin{array}{l}\text { Monthly OI } \\
\text { SST for 1998 }\end{array}$ & $\begin{array}{l}\text { Monthly } \\
\text { Climatological } \\
\text { AMIP SST }\end{array}$ \\
\hline $\begin{array}{l}\text { Initial } \\
\text { atmospheric } \\
\text { condition }\end{array}$ & $\begin{array}{l}\text { Previous } \\
\text { model run }\end{array}$ & $\begin{array}{l}\text { Daily } \\
\text { reanalysis of } \\
\text { NCEP for each } \\
\text { date of April } \\
\text { 1998 }\end{array}$ & $\begin{array}{l}\text { Daily } \\
\text { reanalysis of } \\
\text { NCEP for each } \\
\text { date of April } \\
1998\end{array}$ \\
\hline $\begin{array}{l}\text { Length of } \\
\text { integration }\end{array}$ & $\begin{array}{l}\text { 20 years } \\
\text { continuously }\end{array}$ & $\begin{array}{l}\text { From each date } \\
\text { of April to } \\
\text { August 31 } \\
1998\end{array}$ & $\begin{array}{l}\text { From each date } \\
\text { of April to } \\
\text { August 31, } \\
1998\end{array}$ \\
\hline
\end{tabular}

is larger than the observation.

The simulated ensemble averaged precipitation anomalies (difference between the ensemble average among Group 1 and the climatological mean of the CLIM run) and the observed anomalies (departures from the climatology averaged from 1979 to 1995) for JJA of 1998 are shown in Fig. 3. The observed negative anomalies over the western Pacific and the South China Sea are well reproduced. The model also simulates the positive anomaly over the equatorial region of western Pacific, but with a larger magnitude. We are particularly interested in the positive rainfall anomalies over China, with the centers in the lower reach of Yangtze River valley and a region in the northeast of China. These excessive rainfalls significantly contributed to a serious economic and life damage to China in 1998 (the second largest flood in recent 50 years). The discrepancy is that the positive rainfall anomaly over the lower reach of the Yangtze River valley for the ensemble average is shifted about 5 degrees northward compared to the observation. This positive anomaly in the ensemble simulation is significant at the $95 \%$ level over this area, although, as will be seen, the spread among the 30 members is large.

Since the observed pattern of GH5 anomalies over East Asia is crucial for the formation of rainfall anomalies over China (Tao and Xu 1962), we depicted the ensemble average anomalies of JJA geopotential height at $500 \mathrm{hPa}$ (GH5 hereafter) for 1998 in Fig. 4. One main observed feature of GH5 anomalies is that a positive anomaly exists over the high latitude of Eurasia and a negative anomaly is located over the Bering Sea and the mid-latitude of North America. The second important feature is the strengthening of the subtropical high over the region centered over the South China Sea. It is found that the positive anomaly over the high latitude of Eurasia is captured by the ensemble average of the simulations, although the strength of the simulation is a little smaller. The model also reasonably simulates the stronger subtropical high, but with a much larger magnitude. The model failed to simu- 

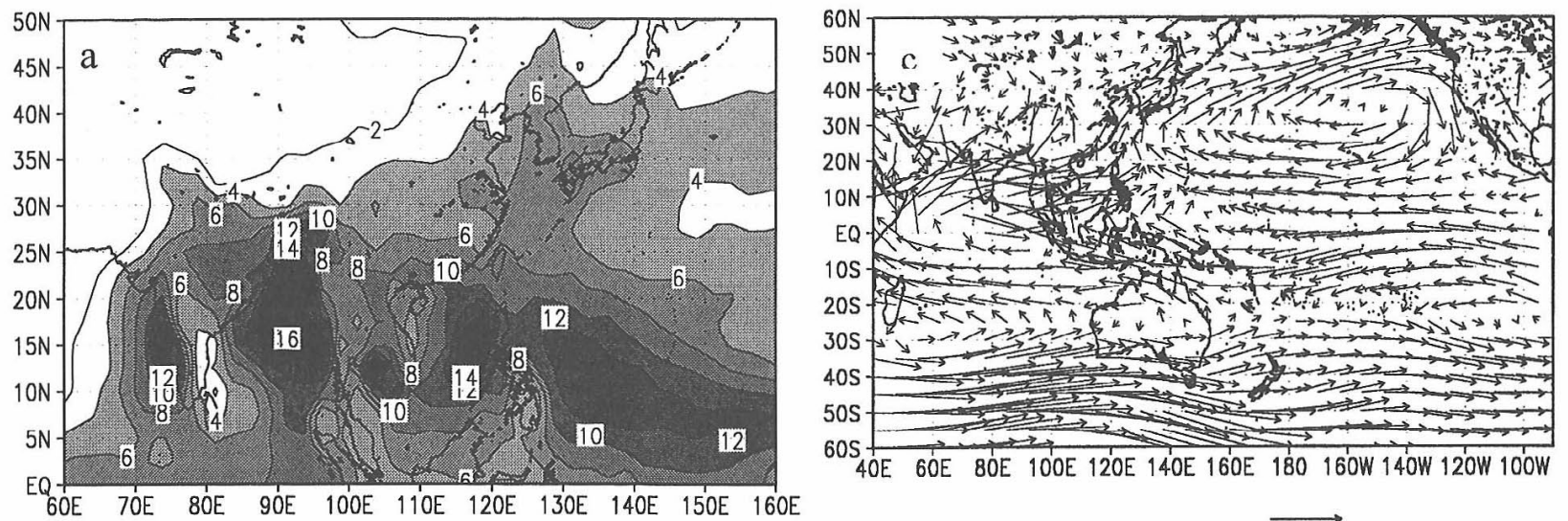

10
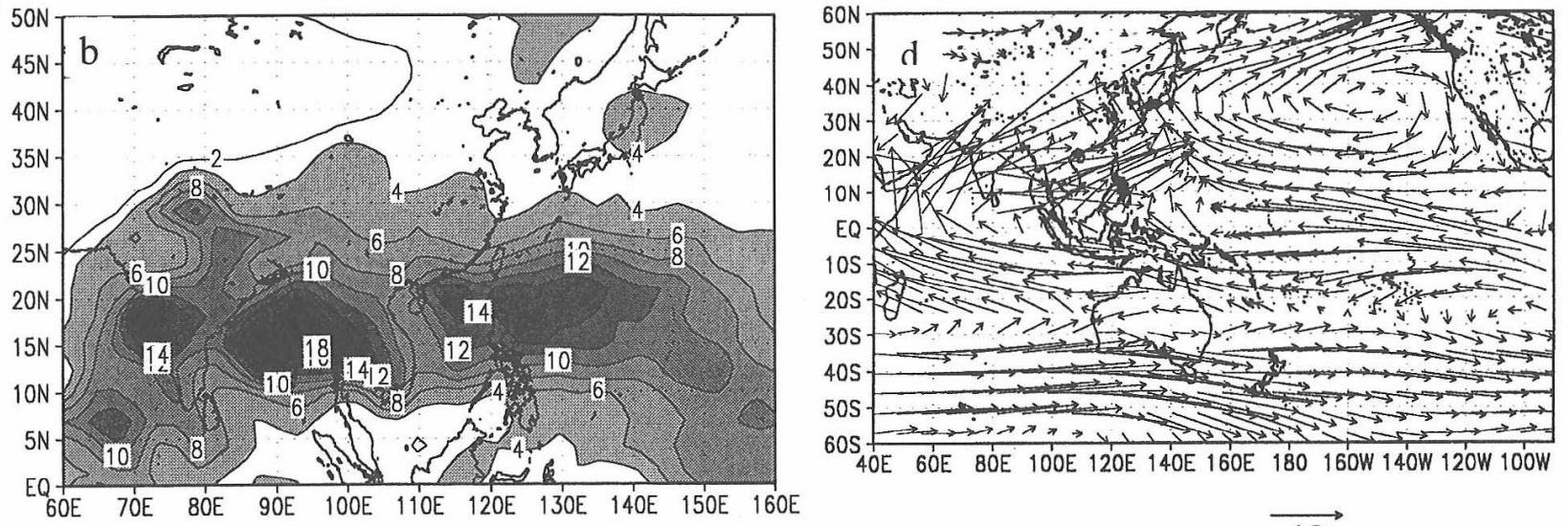

10

Fig. 2. The geographical distributions of the observed JJA mean climatological precipitation (in $\mathrm{mm} /$ day) and $850 \mathrm{hPa}$ wind (in $\mathrm{m} / \mathrm{s}$ ) (a and c) and those simulated by CLIM (b and d). In the precipitation diagrams, areas with magnitude larger than $4 \mathrm{~mm} /$ day are shaded.
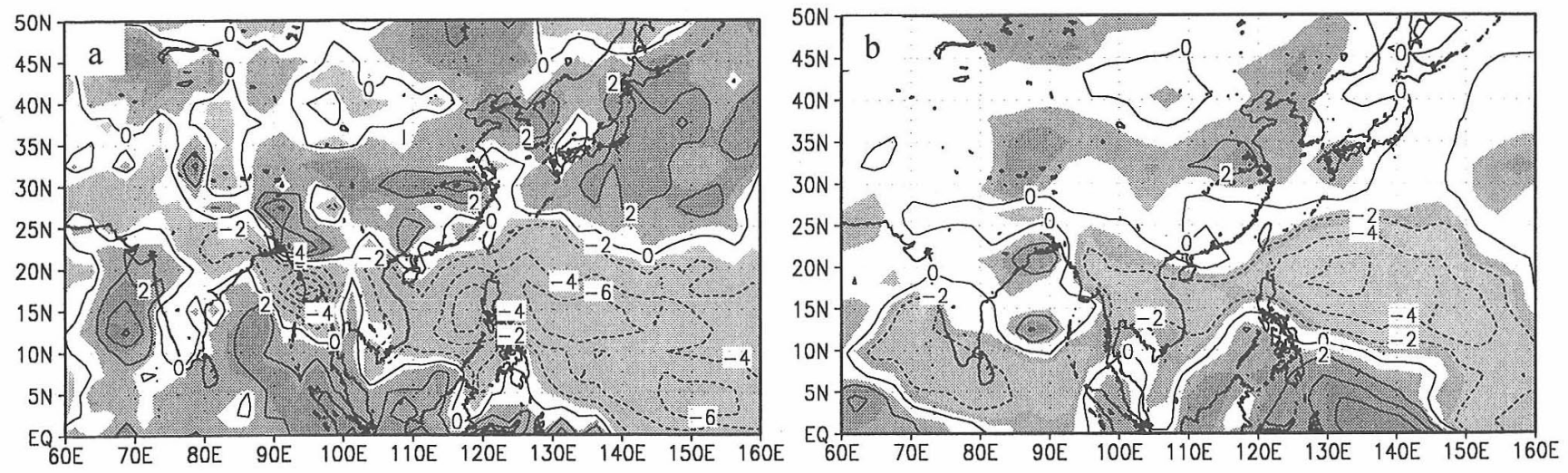

Fig. 3. The geographical distributions of JJA precipitation anomalies (in $\mathrm{mm} /$ day) for the observation (a) and the ensemble average in Group 1 (b). Shaded areas indicate significant anomalies at the $95 \%$ level, estimated by a local student t-test.

late the negative anomalies over the Bering Sea and the mid-latitude of North America. In accordance with the second feature, the southwesterlies associated with the East Asian summer monsoon are stronger. Again, the model simulates a larger magnitude of the wind anomalies at $850 \mathrm{hPa}$ over East Asia (Fig. 5). The model simulates the easterly wind anomalies over the tropical Indian and western Pacific and the northwesterly anomaly over the South Indian Ocean as in the observation, but with much larger magnitudes.

Since most of the individual experiments in Group 1 give almost the same patterns of JJA rainfall anomalies with the observation over the tropical 

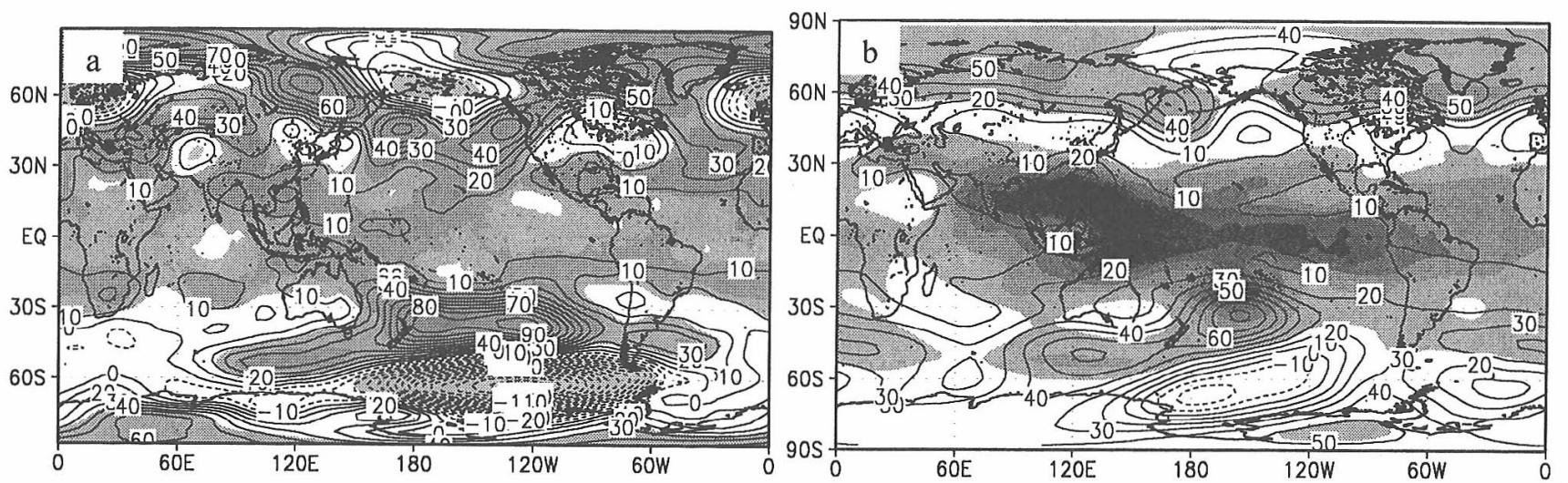

Fig. 4. The geographical distributions of JJA $500 \mathrm{hPa}$ geopotential height anomalies (in $\mathrm{m}$ ) for the observation (a) and the ensemble average in Group 1 (b). Shaded areas indicate significant anomalies at the $95 \%$ level, estimated by a local student t-test.

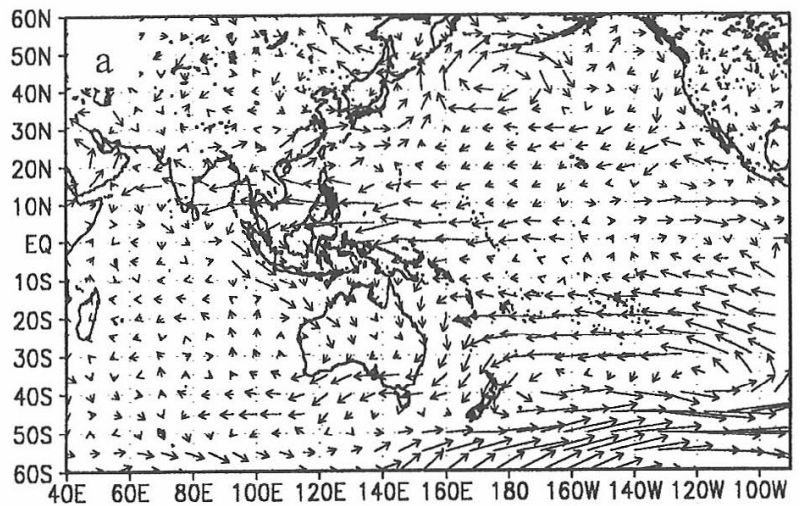

10

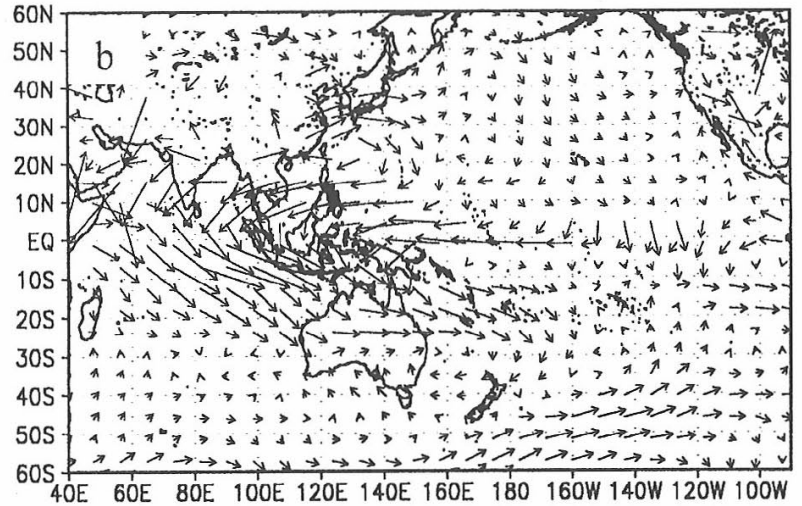

10

Fig. 5. Same as Fig. 4, but for the wind anomalies at $850 \mathrm{hPa}$ (in $\mathrm{m} / \mathrm{s}$ ), without shading.

western Pacific, the SST-induced signals are quite strong over this region. In fact, the positive JJA rainfall anomaly over the lower reach of the Yangtze River valley is qualitatively simulated by most of the individual members. We will find in Section 4 that both the SST and the initial atmospheric condition are important for this positive rainfall anomaly over China.

Since there are large interannual variations for both the spatial pattern of SST anomalies and the initial atmospheric anomalies, the extent to which the seasonal hindcast can be made may change from one year to another. This may especially be true in some extratropical regions like the East Asia, where ENSO-induced climate signal is generally weak in normal years (Rowell 1998).

\section{The impacts of the initial atmospheric anomalies}

There have been some indications on the role of initial atmospheric conditions in the seasonal hindcast. Banerjee et al. (1978) noted that the position of the $500 \mathrm{hPa}$ trough along $75^{\circ} \mathrm{E}$ during April fore- shadowed Indian summer monsoon rainfall. Such kind of empirical relationship has been used in the seasonal prediction of Indian summer monsoon for both the monsoon onset and the monsoon rainfall (Shukla 1987; Das 1987). For the East Asian monsoon, Sun and Sun (1995) found a negative correlation between the East Asian summer monsoon and the preceding winter monsoon as defined by the wind fields at $850 \mathrm{hPa}$.

Therefore, it is an interesting question to ask what role the initial atmospheric anomalies played in the summer climate anomalies over East Asia in 1998, and such may become clear through numerical studies.

The mean April atmospheric condition of 1998 was considerably different from that of climatology. Insofar as GH5 is concerned, large negative anomalies existed over high latitudes of Eurasia and large positive anomalies were located over middle latitudes of Asia. The entire tropical zone was occupied by positive anomalies, and anomalies over North America and the Southern Hemisphere were also large (Fig. 6). 


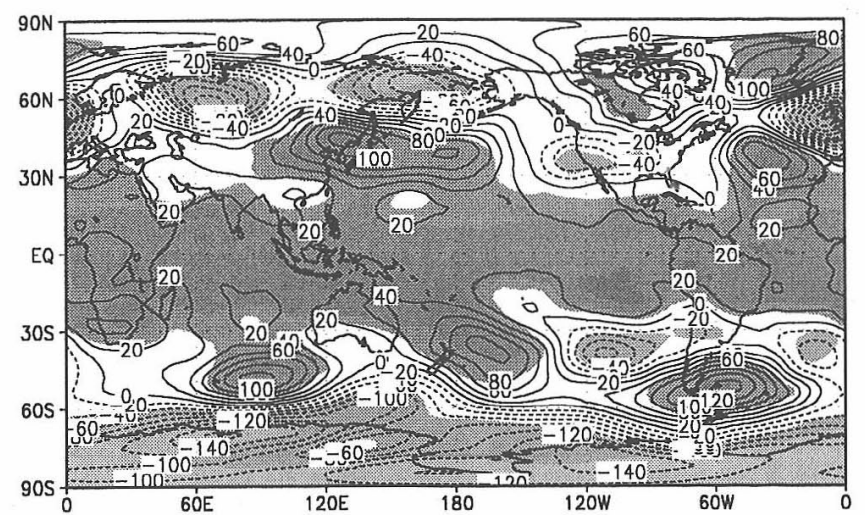

Fig. 6. The geographical distribution of mean April GH5 anomalies (in $\mathrm{m}$ ) for the observation. Shaded areas indicate significant anomalies at the $95 \%$ level, estimated by a local student t-test.

We compared the results of Group 2 and CLIM experiments to assess the impacts of initial atmospheric anomalies. We note that the influence of initial atmospheric anomalies in April on the ensemble JJA GH5 anomalies is significant over large areas of northern high latitudes and over the tropics (Fig. 7). It is quite remarkable that the anomalies of ensemble average JJA GH5 over high latitudes of Eurasia and North America resemble those of the observation (Fig. 4a) or those of Group 1 results (Fig. 4b). The magnitudes of the ensemble average anomalies of Group 2 over these areas are quite close to those of Group 1 results. This indicates that the anomalies of JJA atmospheric circulation over these regions are highly dependent on the initial atmospheric anomalies in 1998. To show more evidence over northern Asia, the cross sections of the ensemble average JJA zonal wind anomalies along $120^{\circ} \mathrm{E}$ are presented (Fig. 8). The negative anomalies in $40^{\circ} \mathrm{N}-50^{\circ} \mathrm{N}$ of the middle troposphere (the weakness of the jet stream) in the observation are simulated by the Group 1 and Group 2 ensemble results (anomaly with respect to CLIM) and the magnitudes are close to each other between Group 1 and Group 2. Therefore the initial atmospheric anomalies in April play important roles in the JJA atmospheric circulation at high latitude, especially over Asia. But the physical mcchanism for this result remains unclear.

However, it can be seen in Fig. 8 that JJA tropical anomalies are controlled by SST anomalies since the main observed features over the tropics can only be simulated in Group 1 where the observed SST anomalies are taken into account. The above main features include the negative anomaly in the lower levels in $0^{\circ}-20^{\circ} \mathrm{N}$, and the positive anomalies in the high levels in $0^{\circ}-20^{\circ} \mathrm{N}$ and in the lower levels in $20^{\circ}-$ $40^{\circ} \mathrm{N}$.

The impact of initial atmospheric anomalies in April can be found in the JJA rainfall anomalies

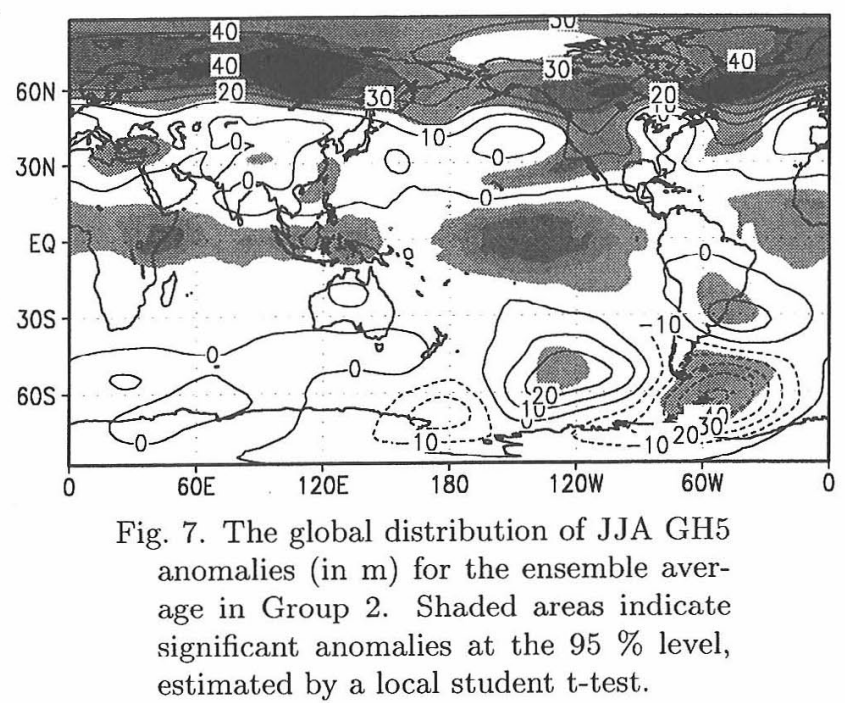

over China as well (Fig. 9). The ensemble JJA rainfall in Group 2 is $1 \mathrm{~mm} /$ day larger than that in CLIM (The location of the anomaly is also shifted about 5 degrees to the north compared to observations). This magnitude of the anomaly is about half of the value between Group 1 and CLIM (Fig. 3b). This again indicates the necessity of taking the initial atmospheric anomalies into account in the seasonal prediction over East Asia, and, again, how the initial atmospheric anomalies influence the summer climate over East Asia needs to be studied.

\section{Summary}

We conclude that the CCSR/NIES model could reproduce a reasonable degree of outlook of the summer climate anomalies over East Asia including the rain over China in 1998 given the observed monthly SSTs and the initial atmospheric conditions in April. The simulated anomalies in JJA GH5 agree well with observations over Eurasia and the tropical western Pacific. The stronger wind over $850 \mathrm{hPa}$ for JJA is reasonably reproduced. The model also captures the weakness of Indian monsoon and the negative precipitation anomaly over the tropical western Pacific. The simulated subtropical high over the South China Sea is also realistic.

Discrepancies between the ensemble simulation and the observation can be found in several aspects. One of them is the larger strength of the simulated wind anomalies at $850 \mathrm{hPa}$ and the OLR anomalies over the tropical western Pacific. The model simulates a northward shift of heavy rain area over China compared to the observation, and it fails to simulate the negative anomaly in JJA GH5 over the Bering Sea along the date line.

This research suggests that the initial atmospheric anomalies in April may have strong impacts on the simulated Eurasia flow pattern and the precipitation anomalies over East Asia in the subsequent summer. However, studies of such impacts in other years 
$\mathrm{hPa}$

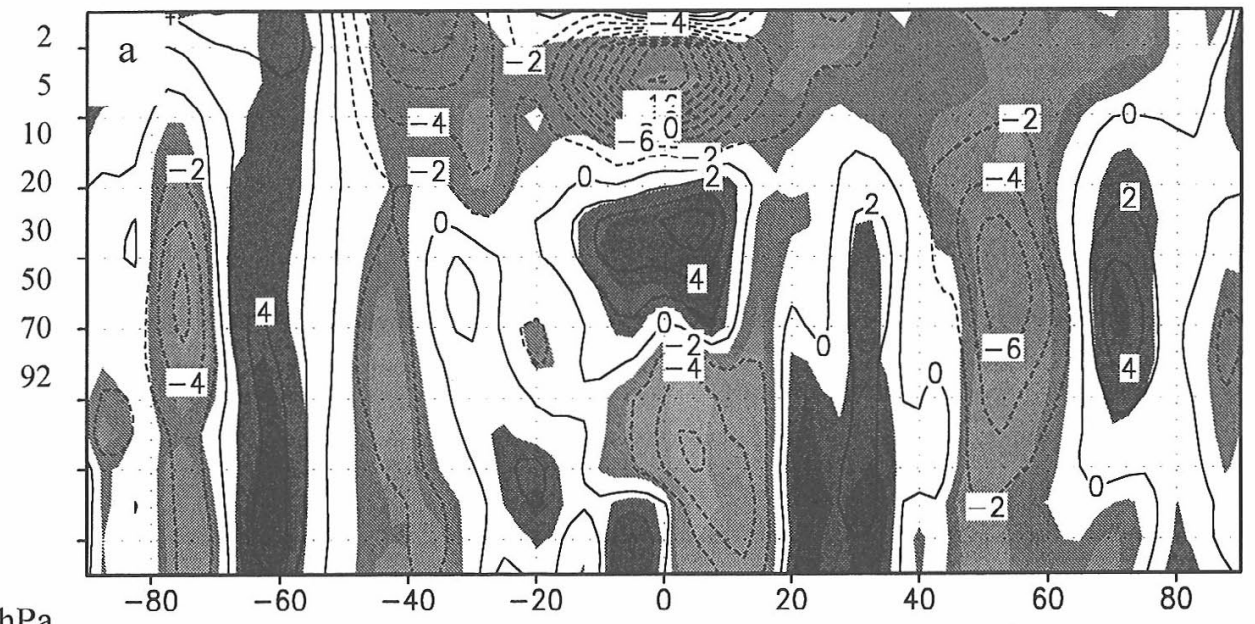

$\mathrm{hPa}$

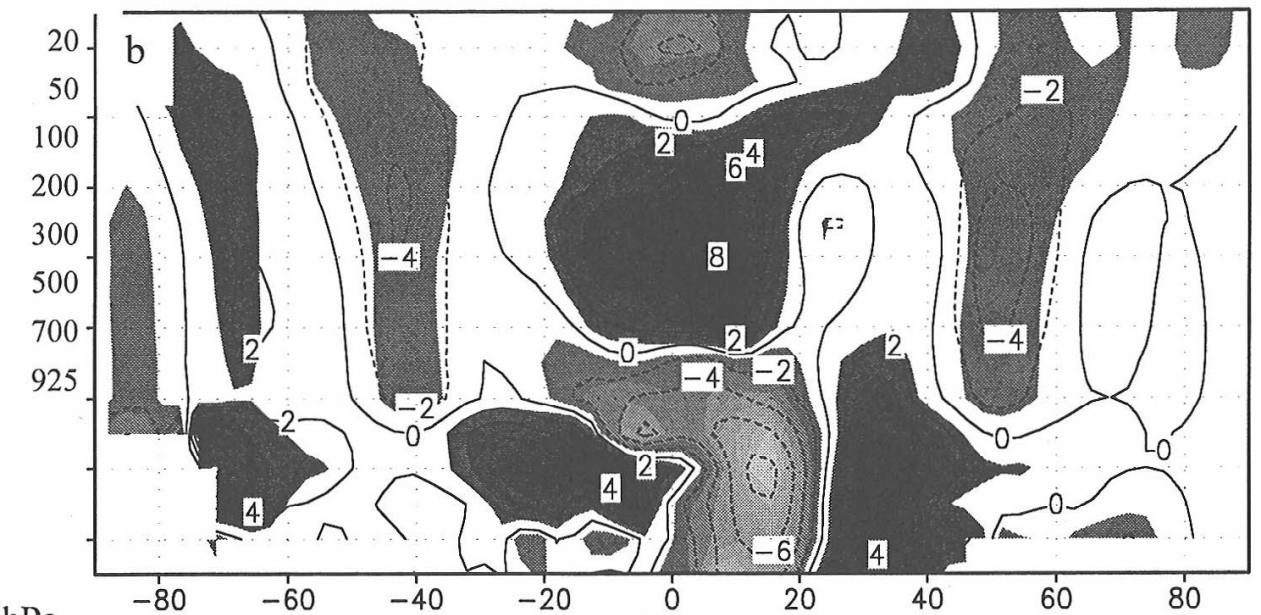

$\mathrm{hPa}$

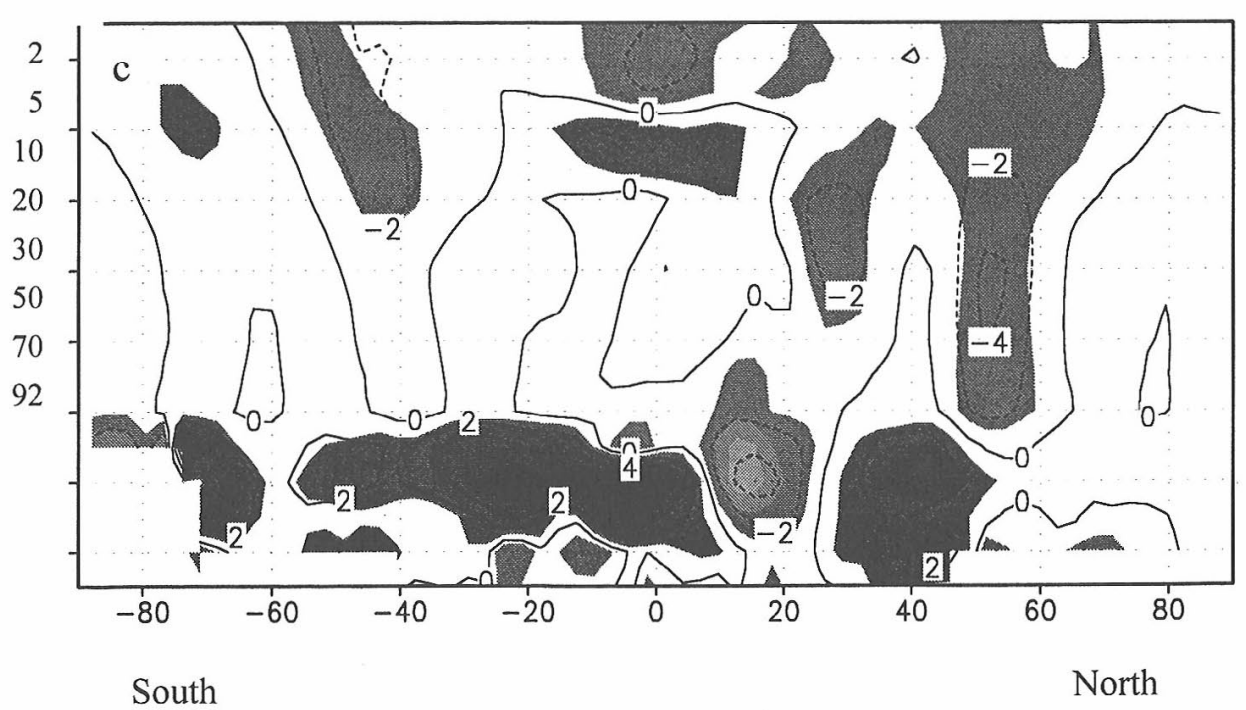

Fig. 8. The latitude-height cross-sections of JJA zonal wind speed anomalies (in $\mathrm{m} / \mathrm{s}$ ) along $120^{\circ} \mathrm{E}$ for the observation (a), ensemble average in Group 1 (b), and ensemble average in Group 2 (c). Shaded areas indicate significant anomalies at the $95 \%$ level, estimated by a local student t-test are shaded. 


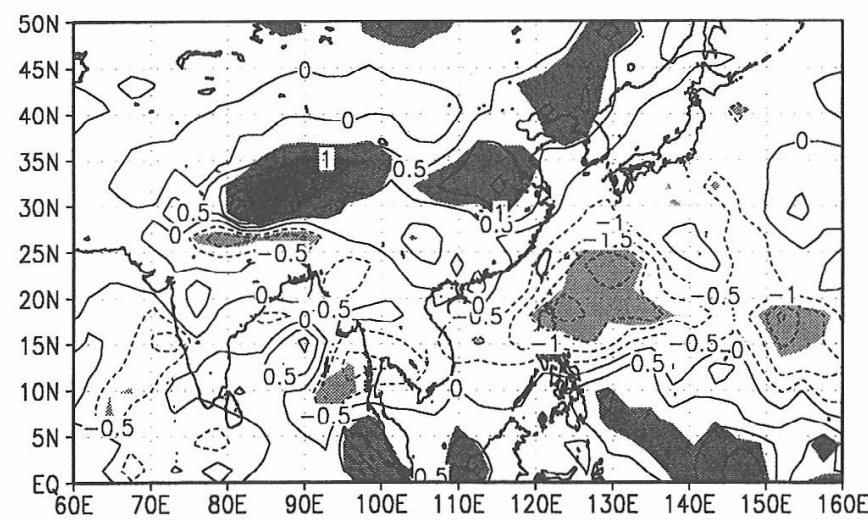

Fig. 9. Same as Fig. 7, but for precipitation anomalies (in $\mathrm{mm} /$ day). Shaded areas indicate significant anomalies at the $95 \%$ level, estimated by a local student t-test.

would be necessary to confirm the above results. At the same time, the study on physical processes responsible for possible relationship between winter (or spring), and summer conditions over Eurasia is required.

The result shows that the enhancement of the western Pacific high-pressure system, as well as the related change of the flow pattern at $850 \mathrm{hPa}$ over the western Pacific and East Asia, were caused mainly by the global SST anomalies. But, which part of the SST anomalies played the key role in this regard remains unknown, and may become clear through more diagnostic analysis and numerical experiments.

Since the year 1998 was a special year both in SST anomalies and in atmospheric anomalies over East Asia, hindcast studies for other years would be valuable.

\section{Acknowledgments}

This research was supported by the STA (Science and Technology Agency of Japan) Fellowship Program. Thanks are due to Prof. A. Sumi of CCSR for permitting the use of the model. Dr. T. Nishimura at FRSGC kindly provided assistance in use of the CCSR/NIES model. Discussions with Dr. X. S. Shen of CCSR were very helpful to this work. The manuscript greatly benefited from careful reviews by the editor Dr. M. Kimoto, and two anonymous reviewers. The first author is very grateful to Dr. S. Hamaguchi for hospitality during his visit at FRSGC. Assistance by Dr. K. Takahashi in use of the computer and network system at FRSGC is also appreciated.

\section{References}

Arakawa, A. and W.H. Schubert, 1974: Interaction of a cumulus cloud ensemble with the large scale environment. Part I., J. Atmos. Sci., 31, 674-701.

Banerjee, A.K., P.N. Sen and C.R.V. Raman, 1978: On foreshadowing southwest monsoon rainfall over India with mid-tropospheric circulation anomaly of April. Indian J. Meteor. Hydrol. Geophys., 29, 425-431.

Brankovic, C. and T.N. Palmer, 1997: Atmospheric seasonal predictability and estimate of ensemble size. Mon. Wea. Rev., 125, 859-874.

Das, P.K., 1987: Short- and long-term prediction in India. In Monsoons, edited by J.S. Fein and P.L. Stephen, 549-578, John Wiley and Sons, New York.

Dix, M.R. and B.G. Hunt, 1995: Chaotic influence and the problem of deterministic seasonal predictions. Int. J. Climatol., 15, 729-752.

Ji, L.R., S.Q. Sun, K. Arpe and L. Bengtsson, 1997: Model study on the interannual variability of Asian winter monsoon and its influence. Adv. Atmos. Sci., $14,1-22$.

Kumar, A. and H.P. Hoerling, 1995: Prospects and limitations of seasonal atmospheric GCM predictions. Bull. Amer. Meteor. Soc., 76, 335-345.

Lau, K.M. and H.Y. Weng, 1998: The multi-scales variation of the global SST and its relationship with the summer precipitation over China (in Chinese). In East Asian Monsoon and the Heavy Rainfall over China, p301-313, Edited by the Institute of Atmospheric Physics Chinese Academy of Sciences, China Meteorological Press, Beijing.

Le Treut, H. and Z.-X. Li, 1991: Sensitivity of an atmospheric general circulation model to prescribed SST changes: feedback effects associated with the simulation of cloud optical properties. Clim. Dyn., 5, 175-187.

Manabe, S., J. Smagorinsky and R.F. Strickler, 1965: Simulated climatology of a general circulation model with a hydrologic cycle. Mon. Wea. Rev., 93, 769798.

Matthews, E., 1983: Global vegetation and land use: New high-resolution data bases for climate studies. J. Clim. Appl. Meteor., 22, 474-487.

McFarlane, N.A., 1987: The effect of orographically excited gravity-wave drag on the circulation of the lower stratosphere and troposphere. J. Atmos. Sci., 44, 1775-1800.

Moorthi, S. and M.J. Suarez, 1992: Relaxed ArakawaSchubert: A parameterization of moist convection for general circulation models. Mon. Wea. Rev., 120, 978-1002.

Numaguti, A., S. Sugata, M. Takahashi, T. Nakajima and A. Sumi, 1997: Study on the climate system and mass transport by a climate model. CGER's $S u$ percomputer Monograph Report, National Institute for Environmental Studies, Environment Agency of Japan (Eds.), 3.

Palmcr, T.N., 1994: Chaos and predictability in forecasting the monsoons. Proc. Indian Natl. Sci. Acad., 60A, 57-66.

Ropelewski, C.F. and M.S. Halpert, 1987: Global and regional scale precipitation patterns associated with the El Nino/Southern Oscillation. Mon. Wea. Rev., 115, 1606-1625.

Rowell, D.P., 1998: Assessing potential seasonal predictability with an ensemble of multi-decadal GCM simulations. J. Climate, 11, 109-120.

Shukla, J., 1987: Long-term forecasting of monsoons. in Monsoon, edited by J.S. Fein and P.L. Stephen, 
523-548, John Wiley and Sons, New York.

Sun, S.Q. and B.M. Sun, 1995: The relationship between East Asian winter monsoon circulation anomaly and the flood and drought in China Yangtze and Huaihe river valley (in Chinese). Acta Meteor. Sinica, 53, 440-450.

Tao, S.Y. and H.Y. Xu, 1962: The features of the atmospheric circulation during the persistent drought and flood over Yangtze River and Huai River valleys

(in Chinese). Acta Meteorologica Sinaca, 32, 1-10.

Webster, P.J. and S. Yang, 1992: Monsoon and ENSO: Selectively interactive systems. Quart. J. Roy.
Meteor. Soc., 118, 877-926.

Wu, G.X. and J.F. Wang, 1996, The SST anomaly over tropics and extra-tropics and the low level atmospheric circulation (in Chinese). Acta Meteorologica Sinica, 54, 385-397.

Xie, P.P. and P. Arkin, 1997: Global Precipitation: A 17-Year Monthly Analysis Based on Gauge Observations, Satellite Estimates and Numerical Model Outputs. Bull. Amer. Meteor. Soc., 78, 2539-2558.

Zeng, Q.C., C.G. Yuan, X. Li, et al., 1997: Seasonal and extraseasonal predictions of summer monsoon precipiation by GCMs. Adv. Atmos. Sci., 14, 163176.

\title{
CCSR/NIES 大気大循環モデルによる 1998 年の中国における 洪水期のアンサンブル事後数值実験
}

\author{
王 会軍 \\ (中国科学院大気物理研究所) \\ 松野太郎・栗原宜夫 \\ (地球フロンティア研究システム)
}

1998 年に中国で起こった豪雨を研究するために、大気大循環モデルによる一連の事後数值実験を行なっ た。モデルの境界条件は、1998 年の月別海面水温で決めた。30 個のメンバーで構成されたアンサンブル 数值積分の各々の大気初期条件には、1998 年の 4 月 1 日から 4 月 30 日までの 00UTC に対する日々の再 解析值を当てた。積雪量、土壤の温度と水分の初期条件には、モデルの気候值を指定した。

30 個の事後実験結果のアンサンブル平均をとると、1998 年夏に起きた雨量の正偏差が、北向き 5 度の 位置のずれで、捉えられた。また、夏季の等圧面高度偏差についても、観測されたパターンが定性的に再 現された。4月の大気の初期偏差は、1998 年夏季のユーラシアと北太平洋上の計算された流れのパターン 及び中国に㧍ける雨量偏差に明らかに寄与したと考えられることが分かった。しかしながら、全体的な結 果は、1998 年の中国の豪雨には熱帯の海面水温偏差が重要な役割を演じたことを示唆する。 